\title{
The ascension and intrusion processes of salt water into aquifers along the tectonic discontinuities in the Żarnowieckie Lake area
}

\author{
Mateusz Damrat ${ }^{1}$, Rafal Warumzer ${ }^{2}$ \\ ${ }^{1}$ Mineral Raw Materials and Fossil Fuels Department, Polish Geological Institute - National \\ Research Institute, Warsaw, Poland \\ ${ }^{2}$ Marine Geology Branch in Gdańsk, Polish Geological Institute - National Research \\ Institute, Gdańsk, Poland
}

\begin{abstract}
In this article, the authors want to pay attention to the intensity of the phenomenon of ascension of salt water from the Permo-Mesozoic formation in the geological structures of the Dębki - Żarnowiec trough. This is a unique area in Poland. The sediments (up to $320 \mathrm{~m}$ in thickness) of the deep Pleistocene trough, cross the Tertiary, Cretaceous and Jurassic deposits, and reach the Triassic layers in the deepest place. An additional aspect is the unquestionable presence of older structures and tectonic loosening, which conditioned the formation of such a large erosion structure. Younger tectonic (neotectonic) activity, both large-scale and resulting from isostatic movements, certainly uses the existing fault network, which in combination with the deeper layer of relatively well-permeable Pleistocene sediments is a system extremely conducive to ascension brines.
\end{abstract}

\section{INTRODUCTION}

The issue of the occurrence of mineralized waters in the aquiferous layers of the Polish Baltic coast was topic of several dozen works in the field of hydrogeology. At present, opinions about the origin of salty waters in the Quaternary aquifer and older formations along the South Baltic coast are clashing. The main processes affecting this phenomenon are ascension and ingression. The area of Żarnowckie Lake trough (Fig. 1), due to its complex geological structure and location in the coastal zone, is an excellent research ground for a better understanding of the regularities at the interface between the two processes.

The geological setting of the Żarnowieckie Lake area is well-known. Apart from the standard recognition works of the geological structure of the country (Ostaficzuk et al. 1976; Ostaficzuk 1978), it was an object of interest due to the occurrence of a hydrocarbon deposit in Cambrian sandstones and due to geotechnical investigation for the planned nuclear power plant operated by PGE EJ 1 in the "Żarnowiec" area (Gniewino and Krokowa municipalities).

General geological and geophysical information about the marine part of the described region is provided by the geological Atlas of the Southern Baltic in the scale 1:500,000 (Mojski eds. 1995). The recognition of the sub-Quaternary bedrock was ensured by the development of a Geological Map of the Baltic bottom without Quaternary deposits (Kramarska (eds.) 1999). The coastline zone was studied by numerous authors from the Polish Geological Institute, which issued in 200365 sheets in the scale 1:10 000 of the geodynamic map of the Polish coastal zone of the Baltic Sea. The location of subglacial forms in the sub-Quaternary relief of the Polish coast was analyzed by the Mojski and Tomczak (1994; Mojski (eds.) 1995). 
Hydrogeological diagnosis within the sheet of the Hydrogeological Map of Poland (in 1: 50,000 scale) was performed by Sierżęga \& Chmielowska (2000). Chlorides anomalies occurring in the groundwaters of aquifers of the Polish coast have been a topic of many works over the last several decades. Works related to the process of ascension and ingression were carried out, among others Dowgiałło (1971), Płochniewski \& Sierżęga (1980), Kawaterkiewicz \& Sadurski (1986), Kozerski \& Pruszkowska (1996), and Krawiec (2013, 2015).

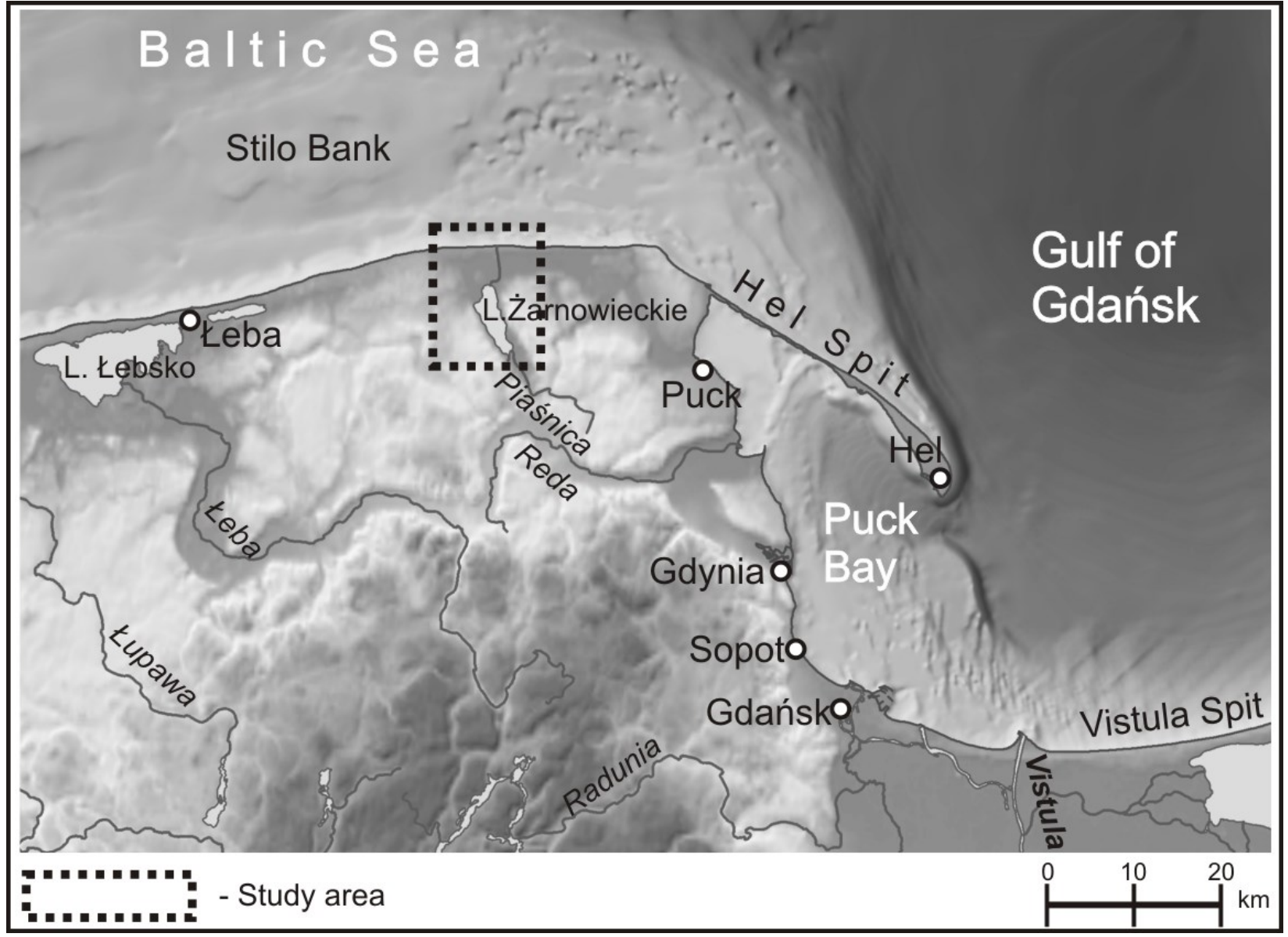

Figure. 1. Localization of the Dębki and Żarnowiec area.

\section{METHODS}

Despite the geological surveys of the Dębki and Żarnowiec region presented above, there is a lack of the synthetic study aimed at taking into account the occurrence of hydrogeological processes, against the background of tectonic and geophysical processes. An additional difficulty is the location and structure of the Dębki - Żarnowiec trough both in the land and sea areas, which results in the lack of continuous geophysical reconnaissance and differences in results. In the case study below, information and data relevant to the migration of salt water in the discussed region are extracted from available sources. A synthetic model was made, including known hydrogeological conditions. An analysis was also made of what research should be done in order to identify the processes occurring on the unique research area, namely the area of the gutter of Żarnowieckie Lake as best as possible. 


\section{RESULTS}

The area of the Dębki - Żarnowiec trough is located in the area of the Peribaltic Syneclise in the NE part of the Leba elevation. The Quaternary basement is built by the cover of the Paleozoic, Mesozoic and Tertiary sediments. The structural stages: Old Paleozoic, PermoMesozoic and Cenozoic were distinguished. Paleozoic (2.6 km in thickness) build Cambrian sandstones and silt-clay sediments, Silurian claystones and the Zechstein evaporates in the top (dolomites, anhydrites and rock salts). Above there are Mesozoic sediments: clays, mudstones and sandstones of the Triassic and the middle Jurassic. The youngest in this series are quartz-glauconite sands and sands with phosphates (upper Cretaceous), (Fig. 2). The area of Żarnowieckie Lake is characterized by a diverse geomorphology. The main form is the buried Pleistocene trough, the development of which was associated with the processes of erosion of glacial waters as well as strong exaration during the Weichselian glaciation. The remaining geomorphological forms occurring in the discussed area are: kame terraces and moraine plateaus. The north part of the Żarnowieckie Lake adjacent to forms associated with lacustrine and marine sedimentation such as lagoons and lake plains, spits and sea terraces.

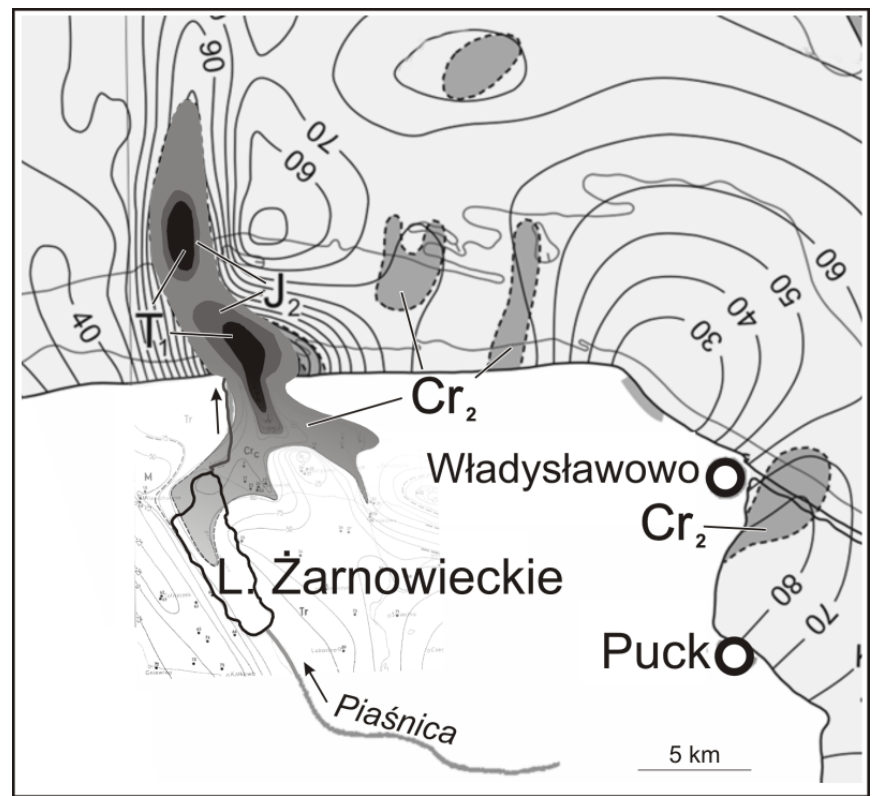

Figure. 2. Reconstruction of pre-Quaternary surface along the Dębki - Żarnowiec trough area. Isolines of Quaternary thickness in meters; after Ostaficzuk (1978) and Kramarska (edit. 1999) modified.

The trough course is close to the meridian (NNW-EES). Quaternary sediments within the research hole in Dębki (Dębki IG-1) were found up to $320 \mathrm{~m}$ - the highest thickness of Q in Poland. At the same time being an erosive surface reached the Triassic (sandstone) formation. Such a large geomorphological form certainly required tectonic conditions and long-lasting and repetitive erosion. The tectonic movements of the Laramiian phase in the upper Cretaceous and Paleogene were certainly an additional factor intensifying erosion, and this tectonic predisposition had a direct impact on the modern location of the Piaśnica Valley and the Żarnowieckie Lake (Tyski 1973). The prolongation of structures observed on land was also documented during geophysical work at sea in the elaboration of the Geological Map of the Baltic bottom without Quaternary formations (Kramarska (edit.) 1999), (Fig. 3).

Within the Dębki - Żarnowiec trough two aquifers belonging to the Quaternary can be distinguished. The first (upper) aquifer is associated with sand-gravel sediments of upper Pleistocene, under the bottom of the lake is spreading to the area of coastal lowlands. In the 
marginal parts of the lake aquifer is not isolated and recharged through the lateral inflow from the plateau. The water table is not strained. The second (bottom) aquifer includes a base part of the trough. It occurs at a depth of 70.0 to $93.5 \mathrm{~m}$ and is underlined with tills of older glaciations and in the top there are Eemian clay and silts (Fig. 4). The contact between both quaternary layers takes place by interaquifer drainage through poorly permeable structures. Outside the Dębki - Żarnowiec trough - in the upland, there is also an aquifer that is associated with Oligocene and Miocene deposits. These aquifers are in direct hydraulic contact with the deeper Quaternary aquifer and form a common quaternarytertiary regional aquifer. The processes of ascension of mineralized waters within the Dębki Żarnowiec trough can be facilitated by the direct contact of the quaternary layer (lower) with the aquifer associated with the Triassic sandstones belonging to the Permo-Mesozoic stage (Fig. 4). This hydrogeological window was found based on the drilling hole in Dębki. The layers are contacted at a depth of $306 \mathrm{~m}$. There is an increase in the salinity of groundwater in the range from $11598 \mathrm{mg} / \mathrm{dm}^{3}$ at depth $40 \mathrm{~m}$, to $13617 \mathrm{mg} / \mathrm{dm}^{3}$ (200 m), (Fig. 4). The course of the contact area includes a narrow zone with a longitudinal course between the northern part of Żarnowieckie Lake and Dębki.

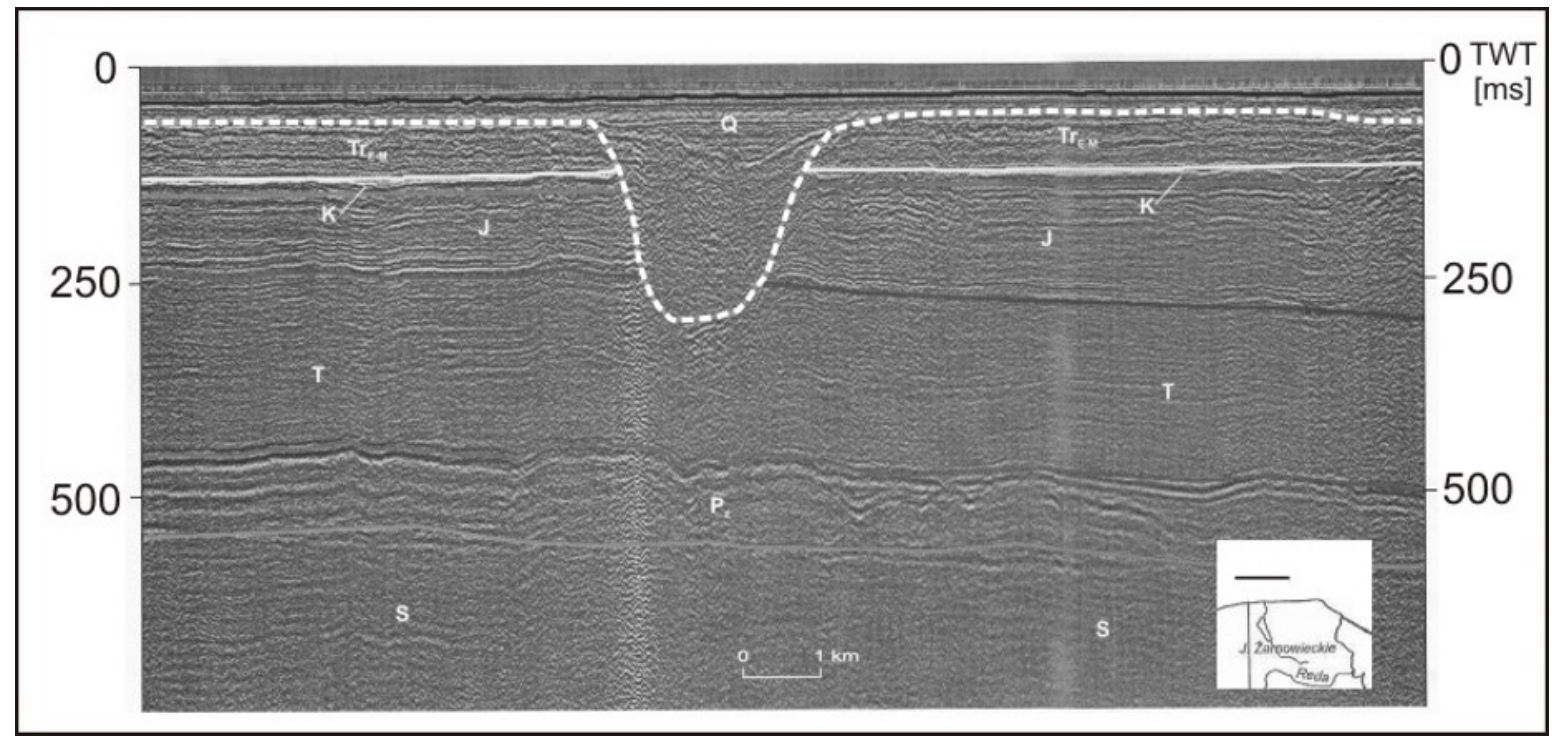

Figure. 3. The offshore geophysical record of Dębki - Żarnowiec trough reaching the Triassic layers; after Kramarska (edit. 1999) modified.

\section{DISCUSSION AND CONCLUSIONS}

It should be noted that according to Płochniewski and Sierżęga, Krawiec (Krawiec 2015, Płochniewski \& Sierżęga 1980), the presence of salt and brackish waters in the analyzed area is related to the ascension of brines from the Mesozoic formations. This ascension takes place along the zones of tectonic (neotectonic) discontinuities and deep erosion in the Quaternary basement. The aforementioned zones of faults are present in the Mesozoic complex both in the land zone and under the sea. The identification of these zones is a serious issue. A series of studies from various branches of geology should be used for this task. Especially hydrogeochemical saline water ingression tests, isotope studies, noble gas determinations and geophysical surveys, both on- and offshore. New drilling hydrogeological wells located in the area of deep structures, buried troughs, with the possibility of sample deep aquifers that may be in contact with the Permo-Mesozoic layers. The occurrence of chlorides anomalies in the groundwaters of the Dębki - Żarnowiec trough 
and the majority of the Polish Baltic coast has a polygenetic nature connected with the processes of ascension, mixing of waters and ingression. Ascension processes as previously mentioned occur in contact zones of Permo-Mesozoic aquifers with younger layers, while the processes of ingression last from approximately 5.5 thousand years when the Littorina Sea reached a sea level similar to today's (Uścinowicz 2003) and its salinity reached above 12 \%o (Bianchi et al. 2000) and even 15-20 \%o (Hyvärinen et al. 1988, Witkowski 1994). An important process affecting the presence of saline and brackish waters was the washing out of saline waters during lower base level of groundwater drainage, which was influenced by ice sheet loads and relaxation during interglacials.

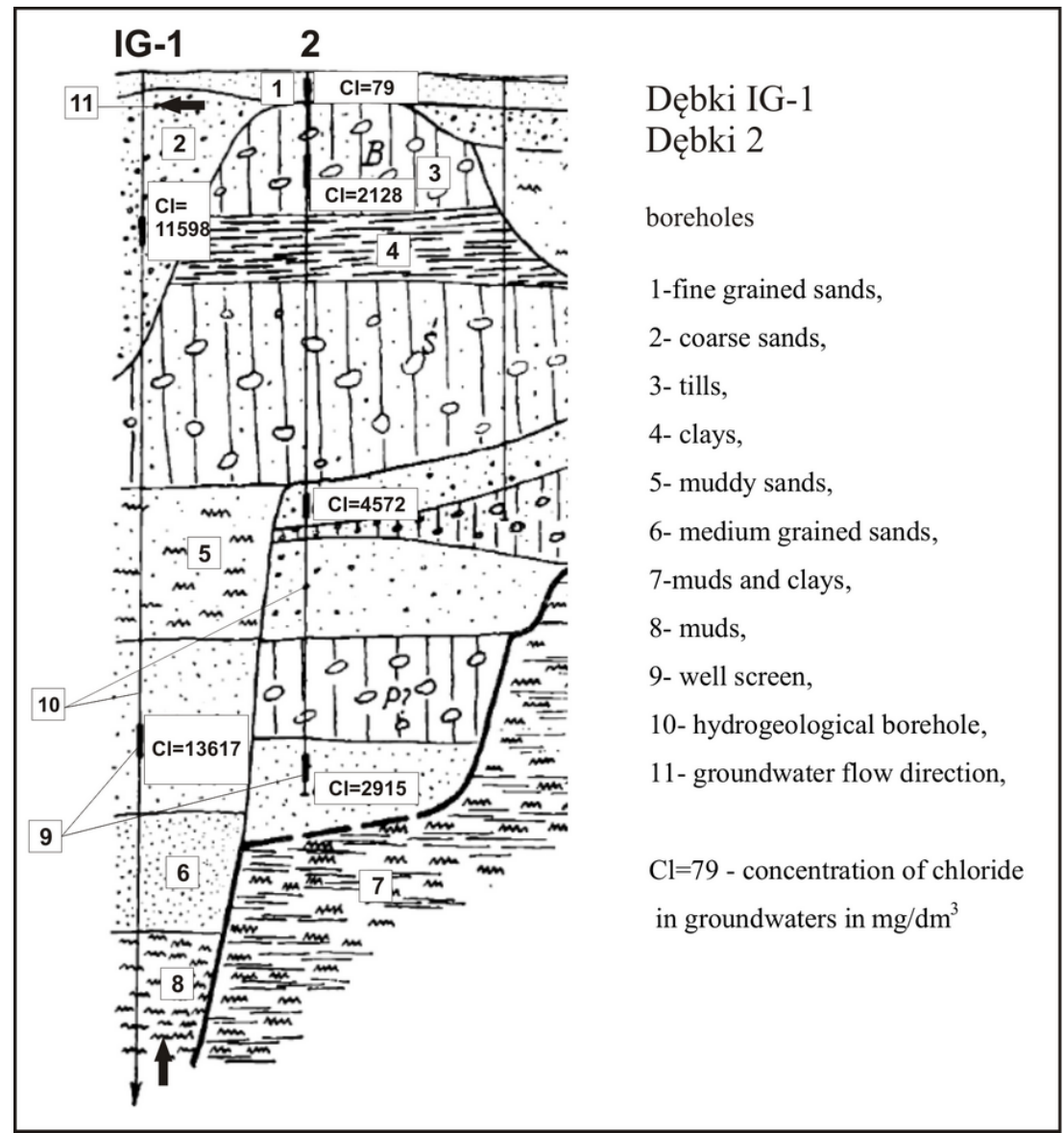

Figure. 4. Hydrogeological cross section of the Dębki - Żarnowiec trough after Kwaterkiewicz \& Sadurski (1986) modified.

\section{REFERENCES}

Bianchi, T., P. Westman, C. Rolff, E. Engelhaupt, T. Andrén, and R. Elmgren. 2000. Cyanobacterial blooms in the Baltic Sea: Natural or Human-induced? Limnol. Oceanogr., 45(3), 716-726,

Dowgiałło, J., 1971, Studium genezy wód zmineralizowanych w utworach mezozoicznych Polski północnej, Biul. Geol. Wydz. Geol. UW, Warszawa

Graniczny, M., 1994, Strefy nieciągłości tektonicznych w świetle korelacji wielotematycznych danych geologicznych, na przykładzie Żarnowca i Ziemi Kłodzkiej, IMBG, 54, PIG

Graniczny, M., Mizerski W., 2003, Lineamenty na zdjęciach satelitarnych Polski - próba podsumowania, Przegląd Geologiczny, nr 6, 51: 474-482. 
Hyvärinen, H., J. Donner, H. Kessel, and A. Raukas. 1988. The Litorina and Limnaea Sea in the northern and central Baltic, in Problems of the Baltic Sea History, edited by J. Donner, and A. Raukas, Ann. Acad. Sci. Fenn., Ser. A3, 148, 25-35.

Kozerski, B. and Pruszkowska, M. 1996. O pochodzeniu zasolenia wód podziemnych polskiego wybrzeża Bałtyku, Inżynieria Morska i Geotechnika

Kramarska, R. (eds.). 1999. Mapa geologiczna dna Bałtyku bez utworów czwartorzędowych w skali 1:500 000, Państw. Inst. Geol., Gdańsk - Warszawa.

Krawiec, A., 2013. Pochodzenie anomalii chlorkowych w wodach podziemnych wybrzeża Bałtyku, UMK, Toruń

Krawiec, A., 2015. Ingresje i ascenzje wód słonych na Pobrzeżu Słowińskim, Przegląd Geologiczny, vol. 63, nr 10/1, 2015, Warszawa

Kwaterkiewicz, A.and Sadurski, A. 1986. Problemy genezy wód zmineralizowanych w sąsiedztwie jeziora Żarnowieckiego, Annales Societatis Geologorum Poloniae

Mapa geodynamiczna polskiej strefy brzegowej w skali $1: 10$ 000. 2003. Praca zbiorowa PIG-PIB

Mojski, J.E. and Tomczak, A. 1994. Większe formy subglacjalne w rzeźbie podczwartorzędowej polskiego wybrzeża. Acta Univ. Nicolai Copernici. Geografia XXVII. Nauki Mat-Przyrod. z. 92. Torun.

Mojski, J.E., (eds). 1995. Atlas geologiczny Południowego Bałtyku (1:500 000). Państwowy Instytut Geologiczny.

Mojski, J.E. 2000. The evolution of the Southern Baltic Coastal Zone. Oceanologia 42 (3), Gdańsk.

Ostaficzuk, S., Jakubicz, B. and Skompski, S. 1976. Szczegółowa mapa geologiczna Polski w skali 1:50 000 Arkusz Sławoszyno. Wyd. Geol., Warszawa.

Ostaficzuk, S. 1978. Objaśnienia do Szczegółowej mapy geologicznej Polski w skali 1:50 000, Arkusz Sławoszyno. Wyd. Geol., Warszawa.

Płochniewski, Z. and Sierżęga, P. 1980. Warunki hydrogeologiczne w rejonie Elektrowni Jądrowej Żarnowiec, Mater. Konf. Bezpieczeństwo Elektrowni Jądrowych i Ochrona Środowiska, Bydgoszcz

Sierżęga, P. and Chmielowska, U. 2000. Mapa hydrogeologiczna Polski w skali 1: 50 000, arkusz Sławoszyno, PIG, Warszawa

Uścinowicz, S. 2003. Relative sea level changes, glacio-isostatic rebound and shoreline displacement in the Southern Baltic. Polish Geol. Inst. Sp. Papers, 10: 1-79.

Witkowski, A. 1994. Recent and fossil diatom flora of the Gulf of Gdansk, southern Baltic Sea, Origin, composition and changes of diatom assemblages during the Holocene, Bib. Diatomologica, $28,315 \mathrm{pp}$.

Contact Information: Rafał Warumzer, Polish Geological Institute - National Research Institute, Marine Geology Branch, Kościerska 5 str., 80-328 Gdansk, Poland, Tel. +48 585542909 ext. 213, Email: rwar@pgi.gov.pl 